\title{
Do deep pockets have more political influence?- - the size of private enterprises and their strategy selection in resolving administrative disputes
}

Yingying $\mathrm{Ji}^{i^{*}}$ and Xiaoguang Fan ${ }^{2}$

* Correspondence: jiyingying@shu. edu.cn

'Shanghai University, Shangda Road 99, Shanghai, China

Full list of author information is available at the end of the article

\begin{abstract}
Fitting multivariate models to the China Private Enterprises Survey (2006) data, this article reveals the differentiation of state-business relationship as a function of a private enterprise's economic capital, thereby to a certain extend challenges the dominant paradigm of clientelism. When resolving disputes with the government, private enterprises with more economic capital are more likely to directly contact the government agency, displaying greater political privilege. On the other hand, private enterprises with middle-range economic capital show higher preference to take advantage of business associations or particularistic relationships. However, instead of economic capital, it is the Communist Party membership of private entrepreneurs that influences their contentious strategies. There is also regional variation in the selection of strategies. This article casts doubt on the existence of a "capitalist class" in China. Under the specific context of the Chinese society, characteristics of the private economy influence the path by which economic power transforms to political power.
\end{abstract}

Keywords: Economic capital, Clientelism, State-business relationship, Bargaining power, Business associations

\section{Introduction}

The supremacy exerted by the dominating group over other social groups is achieved mainly through economic, political, military, and religious avenues (Domhoff 2009). The concrete extent and approach through which the economic power is translated to political power has been the focus of social science in discussing the power structure of modern society. This transformation and its effects are configured by both the polity itself and the characteristics of the economy (Salamon and Siegfried 1977). In the context of transitional and developing countries, the relationship between political elites and economic elites is the key to understanding political reform and social change. Thus the relationship between the government and emerging private entrepreneurs in China has been the central concern of political science, sociology, and even economics when it displays important significance in the developing market economy, the improving governance structure, and the changing social structure.

(c) The Author(s). 2019 Open Access This article is distributed under the terms of the Creative Commons Attribution 4.0 International License (http://creativecommons.org/licenses/by/4.0/), which permits unrestricted use, distribution, and reproduction in any medium, provided you give appropriate credit to the original author(s) and the source, provide a link to the Creative Commons license, and indicate if changes were made. 
Hitherto academic research has reached the consensus that the state-business relationship in China is characterized by the link between officials and private entrepreneurs though intense social networks, the clientelist essence of the relationship, and the co-optation facilitated by formal institutions (Huang 2014a). Public opinion also agrees that the high risk of corruption in the official-merchant relationship demands urgent systematic resolutions. However, the above perspective has neglected the fact that the current state-business relationship in China is changing. Existing research thus fails to capture the complexity of recent empirical development. On the one hand, a group of major private entrepreneurs has attempted to exercise influence on government policies through building "online think tanks". ${ }^{1}$ On the other hand, a number of cases in which private entrepreneurs have joined together to sue the local

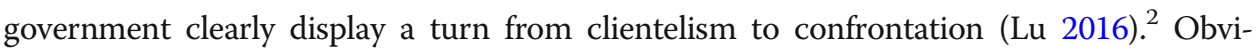
ously, large enterprises and small- and medium-sized enterprises should not be combined into one single position. In short, the current state-business relationship in China displays diversity and complexity beyond the scope of one single theoretical mode.

Some recent research has highlighted the trend of differentiation. Motivated by the "tournament" model, local governments prefer those big enterprises that can bring more economic contributions to taxes or increase the employment rate. The economic status of private enterprises and foreign-invested companies can thus greatly influence their bargaining power with the local government, which then leads to differentiation of the local state-business relationship (Huang 2013; Keng and Chen 2015; Ji 2015). Existing research generally shows two characteristics. First, although these researchers agree that the bargaining power of the enterprise influences its relationship with the local government, the concrete mechanism, degree, and even direction of that influence need more clarification. Second, most of this research proposes hypotheses through case studies conducted in specific field sites. The general pattern of the state-business relationship in China and the testing of these hypotheses need an analysis of national survey data.

Based on the findings of previous studies, this article proposes that the state-business relationship in contemporary China can be categorized into three types: Clientelism, Organizational participation, and Contention. However, existing research does not identify the determinants or conditions that can explain the differentiation among the above three types. This article thus fills this gap by revealing how the economic status of private enterprises influences the differentiation of the state-business relationship in contemporary China. More specifically, the economic status or economic contribution (hereafter referred altogether as "economic capital") of private enterprises determines their latent or visible bargaining power, which then influences the strategy selection of private enterprises in resolving administrative disputes with the local government. The statistical findings reveal the following pattern. First, facing administrative disputes, private enterprises with higher economic capital are more likely to communicate with the government agencies through formal institutional channels. Second, there is an inverted- $U$ shape relationship between economic capital and the selection of the associational approach or the clientelist approach in resolving administrative disputes. Compared to enterprises with higher or lower economic capital, private enterprises with middle-scale economic capital are more likely to seek help from business associations or particularistic personal relationships with officials. 
The differentiated pattern of the state-business relationship in China depicted here has important theoretical implications. First, beyond the scope of the clientelist perspective that has been dominating current research, the Chinese state-business relationship may be differentiating toward different types, among which the clientelist type is only one option. Private enterprises with different economic capital gain different bargaining power and choose different strategies to resolve disputes with administrative agencies. Second, large private enterprises in China currently are enjoying more de facto institutional privileges. This may be significant for lasting political development. Third, medium-scale private enterprises are more likely to be involved in economic associations. This may indicate that a kind of organized activism is developing among a specific group of Chinese merchants.

\section{Literature review}

The bargaining mechanism, including whether private entrepreneurs can articulate their collective interests to influence government policy, and the concrete approach and extent of their influence is the central concern in the study of Chinese politics. Lee and Zhang (2013) argue that the grassroots state in China absorbed popular protest through three microfoundations: protest bargaining, legal-bureaucratic absorption, and patron clientelism. The framework of this article is inspired by Lee and Zhang's analyses, but also differs from it. Taking the view of the state, Lee and Zhang unravel how grassroots officials understand, choose, and practice different strategies, but they pay less attention to how societal actors choose, borrow, and resist certain bargain mechanisms. For example, when is protest bargaining chosen over patron-clientelism for what kind of conditions? While agreeing that the bargain mechanism is the key to understanding the state-society relationship in China, this article pays more attention to answering how the bargaining power of societal actors influences their specific choice of bargaining strategies and the bargaining process. Specifically, the central question of this article can be put in the following way: along the increasing weight of private economy in China, can the economic capital of private entrepreneurs be translated into their bargaining power? How does the possession of bargaining power influence their choices among different bargaining strategies?

We propose three main bargaining mechanisms between the government and private entrepreneurs: clientelism, which is concerned with the coalition and interest exchange between entrepreneurs and politicians; organized associations, which is concerned with the solidarity of organized individual businesses; and contentious activism, which is a confrontational way to defend rights or interests. Private entrepreneurs' bargaining power influences their choice among these different bargaining strategies (see Fig. 1 for an analytical framework). Existing research has thoroughly discussed clientelism and organized business associations. There is an empirical emergence of protests by Chinese businesses, but the topic has attracted less academic attention. This paper also contributes to this discussion.

Generally speaking, the state-business relationship includes a lasting and stable pattern that reflects how the businesses communicate their interests and appeals to the state. As a quantitative work, the empirical analysis of this paper focuses on 


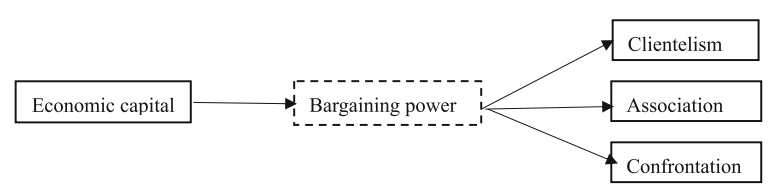

Fig. 1 Analytical framework

strategy selection of private entrepreneurs in resolving administrative disputes for two reasons. First, this paper contributes to expanding the scope of the issue to all types of disputes resolution in China. In previous quantitative research regarding dispute resolution, ${ }^{3}$ class, social networks, clan, region, and political connections have been found to influence the strategy selection in resolving civil disputes (Michelson 2007; Cai 2008; Chen and Wu 2010; Lu and Yang 2010; Fan et al. 2016). Chen (2009) uses CGSS (2005) to reveal the general pattern and major determinants of administrative dispute resolution in contemporary China. However, both quantitative analysis of administrative dispute resolution and the resolution strategies of private entrepreneurs need further analysis. Second, a description and a causal analysis of the model of dispute resolution of private entrepreneurships can benefit the general understanding of the relationship between the Chinese state and businessmen group. This paper also contributes to deepening and completing our understanding of the state-business relationship in China. Disputes with the governmental administrative agencies essentially are conflicts between state and society, which is a facet of the state-society relationship that has the highest tension.

The following section reviews discussions on the three bargaining mechanisms in contemporary China: clientelism, organized association, and contention. Hypotheses will be presented accordingly.

\section{The clientelist perspective and its modification}

Clientelism has undoubtedly been the dominating perspective in understanding the elite-mass relationship, bureaucratic operation, and grassroots politics in China. Researcher's understanding of the importance and scope of this mechanism, however, has been changing.

At the core of clientelism is the assumption that the state monopolizes power and resources and dominates the allocation of resources. In contrast, social groups, including private entrepreneurs, have to gain information and resources and solve problems through particularistic relationships with individual officials. Wank (1999) proposes the concept of "symbiotic clientelism" to modify the traditional observation. Symbiotic clientelism differs from the traditional concept of clientelism fundamentally. Government officials and private entrepreneurs are now mutually dependent on each other instead of the latter having a unidirectional reliance on the former. That local governments are now also counting on private entrepreneurs to boost local economic development which reduces inequality between these two actors. Yet this new mutual dependence does not change the essential function of the clientelist network in Chinese society, namely serving as a bridge between the bureaucracy and 
the market, laying the institutional foundations for the emerging market economy. Thus, from the clientelist perspective, a particularistic personal relationship with officials will always be the first choice of private entrepreneurs to acquire resources and solve problems.

The formation and consolidation of clientelism networks are rooted in the political economy of the state socialism system. Thus, it is reasonable to infer that the transformation of the state socialism system would also lead to the decay or modification of clientelism. Two possibilities have been identified by previous research. First, Guthrie (1998) finds an increasing awareness among Chinese people of the difference between guanxi and "pulling guanxi" (走关系). The former is a legitimate behavior of utilizing social network to get convenience in the market, which can happen anywhere. The latter refers to the behavior of avoiding legal or institutional regulations by seeking patronage from social networks. Along with the development of the rational legal system and the legal-rational culture, the significance of both guanxi and "pulling guanxi" will diminish. Keng and Chen's case study (2001) supports this prediction. The characteristics of social networks that weave the officials and businessmen together are developing toward equality and nondependence in market reform, but are not yet fully transformed. Lee and Zhang (2013) also agree that the importance of clientelist networks is declining.

Second, despite the general observation that the importance of clientelist networks may decline, some research works indicate that private enterprises may be influenced to different extents according to their scale. Huang (2013) argues that private enterprises are actually embedded in the institutional structure of the state. The specific positions that enterprises occupy determine their bargaining power vis-a-vis the government and their participation to political decision-making. For example, private enterprises supported by the key industrial projects of the government and pillar enterprises accounting for a great proportion of the local gross domestic production (GDP) or fiscal income exert visible influence on policy decisions. Ji (2015) finds that local governments are predominantly driven by concerns of economic development. In this context, key enterprises that greatly contribute to the local economy, raising employment rate and tax revenue, enjoy greater access to the policy process, higher priority, and more chances to negotiate with the local government through direct institutional arrangements than small- and medium-sized enterprises. Keng and Chen (2015) propose the concept of "reversed rent-seeking." The local government, which is anxious to develop the economy, has to provide many subsidies, tax refunds, and policy privileges to attract foreign enterprises, which can bring out monopolistic advantages and higher profits. This kind of reversed rent-seeking is not limited to foreign investments.

In summary, enterprises that are on a large scale and have huge tax revenue numbers and heavy weight in the local society are more likely to maintain close and good interactions with the local government. They prefer to contact with local government agencies directly through formal institutions rather than exert pressure on the local government or use confrontational strategies. Thus hypothesis 1 is formulated as follows:

Hypothesis 1: Private enterprises with higher economic capital are more likely to resolve administrative disputes by negotiating with the local government through formal administrative channels. 
Maintaining clientelist networks costs private enterprises significant resources, time, and energy, which may be unaffordable for small and petty enterprises. Given the current market development and institutional environment, it is not necessary for small private enterprises and the self-employed to interact closely with the local government. In other words, they are no longer very dependent on the local government. Thus, they may tend to run their own course without interacting with officials in order to avoid the cost of maintaining clientelist networks. At the same time, although a few of the biggest taxpayers did enjoy more bargaining power than others, China's taxation system would still motivate the majority of middle-scale private entrepreneurs to seek clientelist networks in order to reduce the risks of tax avoidance or to obtain other benefits (Zhang 2017). Therefore, it is reasonable to argue that while large enterprises gain more access to formal institutions, middle-sized enterprises become actively involved in clientelist networks, and small enterprises may just emerge and perish on their own. Hypothesis 2 is formulated as follows:

Hypothesis 2: Private enterprises with the highest or lowest economic capital are less likely to use informal clientelist networks, while private enterprises with median-level economic capital are more likely to use informal clientelist networks to resolve administrative disputes.

\section{Development of business associations}

Beyond the scope of clientelism, recent research also points out the emerging organized activism in Chinese politics, especially as business associations are playing increasingly visible roles in policy processes (Jia et al. 2004; Kennedy 2005; Jiang et al. 2011; Gao and Tian 2006; Deng and Kennedy 2010; Tsai 2007; Huang 2014a; Ji 2016). However, it is still unclear exactly to what extent business associations can facilitate interest intermediation and influence governmental policy decisions. A concern of this article is to identify what kinds of private enterprises utilize business associations to assert interests and solve problems.

Dickson (2009) argues that the majority of Chinese private enterprises are smalland medium-sized enterprises. This disparity of enterprise scale inhibits the possibility of effective collective action, but helps to solidify clientelist networks. In other words, Dickson presumes that small and medium enterprises in China tend to construct patron-client relations rather than organize formal associations. Lucas (1997) argues that in developing countries, large enterprises possess resources that are easily concentrated and mobilized, and that usually also share common targets with the state in industrial transformation. These factors are all helpful for large enterprises in performing effective associational actions. However, resources are dispersed in a limited way among small entrepreneurs and are thus difficult to mobilize to support collective action. Haggard et al. (1997) argues that the smaller the size of the private sector, the weaker its ability, and the harder it is for it to influence government policy. In contrast to these above opinions, You (2014) proposes that the big groups were more inducive to official corruption as they could provide officials with more opportunities of rent seeking, whereas the organizational structure of small- and medium-sized enterprises reduces corruption. Hence, the South Korean bureaucracy 
is believed to be more corrupt than that of Taiwan, as the Taiwanese market is dominated by small and medium enterprises, whose structure suppresses corruption. Kennedy (2005) provides a case study of Chinese national business associations to support You's hypothesis. In China, the electronic and software industry is mainly composed of small- and medium-sized enterprises. It is easier for these members to communicate and negotiate for common pursuits. Business associations in the electronic and software industry are thus more active and effective in business lobbying than the iron industry, which is dominated by large state-owned enterprises.

Moreover, it is necessary to differentiate the action logics of businesses of different sizes. Large enterprises that carry much more bargaining power probably avoid involvement in business associations, worrying they would get free ridden by those small enterprises that lack policy influence. Small enterprises and the self-employed lack bargaining power to negotiate with the local government directly. It is thus reasonable to argue that medium-sized enterprises would prefer to join together and enhance their collective bargaining power through organized associations. They still lack institutional chances to contact local governmental agencies directly and avoid any aggressive confrontations that would lead to political risks or economic costs.

To summarize, the extant research proposes opposite hypotheses on the relation between the economic scale of enterprises and their preference for business associations. Hypothesis 3 proposes that there is an inverted- $U$ shape correlation.

Hypothesis 3: If the economic capital of private enterprises is located in the middle range, enterprises are more likely to use business associations to resolve administrative disputes. However, if economic capital is approaching the highest or lowest terminal, enterprises are less likely to resort to business associations.

It needs to be emphasized that this article focuses on whether private enterprises actually solve problems through associations, instead of simply holding membership. This distinction between nominal involvement and employing an associational approach is necessary in the Chinese context. The state uses a corporatist system to co-opt private entrepreneurs. Many private entrepreneurs may join all kinds of associations formally but do not really participate in associational activities. Membership itself does not necessarily mean the entrepreneur really takes associations as a means to assert pursuits or solve problems. Fieldwork has discovered the dilemma of inactive members and low organizational cohesion ${ }^{4}$ that many business associations face.

\section{The contention between government and business}

Both clientelist networks and formal associations belong to the nonconfrontational variation of the Chinese state-business relationship. This type has been a dominating focus, while the contentious type of relationship has been neglected. Recently, confrontations between private entrepreneurs and the local government have been increasingly reported. ${ }^{5}$ A few research works have attempted to answer what kinds of private entrepreneurs or enterprises are more likely to use lawsuit against local governments, petition to higher authorities, or popular media exposure. The existing explanation is complicated. 
Some case studies find that economic capital is the key independent variable. $\mathrm{Lu}$ (2016) analyzes the Shanbei Oil Event and argues that the "growth coalition" between local government and business groups was not always formidable and could be transformed into intense conflicts between the state and society, leading to political crisis. In the Shanbei Oil Event, large private entrepreneurs chose to compromise or quit collective resistance efforts; the small- and medium-sized private entrepreneurs ultimately composed the major force of resistance. On the will and ability to resist, Tsai (2007) identifies a four-category typology of private entrepreneurs in China, namely the grudgingly acceptant, the loyally acceptant, the avoidant, and the assertive. The assertive type mainly refers to the self-employed or petty entrepreneurs. Ji (2015) argues that the self-employed basically carry no weight in the local political economy and thus have no direct influence on local government through institutional channels. Since there was no need for them to fear destroying personal networks with familiar officials or losing political and economic capital, they were more likely to become involved in collective resistance in order to push the local government to manage local affairs. The self-employed or petty private entrepreneurs who identified themselves as weak had to use extreme and confrontational strategies to attract the attention of the local government and the sympathy and support of public opinion since they had no other leverage. This argument is also supported by the research on contentious politics in China (Dong 2008). A reasonable hypothesis would thus be that the self-employed or petty entrepreneurs with little bargaining power are more likely to oppose the local government than larger ones.

However, other studies argue that the choice to perform collective actions is conditioned by noneconomic factors. Li (2013) finds that a few private entrepreneurs chose to sue tax agencies, which were regarded as one of the most powerful departments of the Chinese government. According to the Supreme People's Court, out of 136,353 administrative lawsuits, 405 were against tax agencies. After reviewing all administrative lawsuits regarding taxation in Henan Province during the period of 2009-2011, Li concludes that entrepreneurs are likely to file lawsuits against tax agencies when they (a) are not registered locally, (b) face seriously broken state-business relationship, (c) have powerful allies in the local state, and (d) wrongly estimated their chance of winning. Ang and Jia (2014) argue that owners of private enterprises with political connections, namely those that formerly served as government officials or representatives in the People's Congress, were more likely to initiate lawsuits to resolve disputes than those without political connections because enterprises with political connections possessed more relevant knowledge or experience required for using legal approaches. Similarly, Huang and Chen (2015) find that xiahai (下海) entrepreneurs who used to work inside the government were more inclined to challenge and exert external pressure on local governments to settle disputes through lawsuits or media exposure than those entrepreneurs who had never worked in party-state agencies. Michelson (2007) also finds that individuals with more political capital were more likely to resort to legal approaches or government agencies to settle all types of disputes. In conclusion, political connections or political capital significantly influences the resolution of civil and administrative disputes.

Based on above discussion, this article proposes two hypotheses: 
Hypothesis 4.1: Private enterprises with lower economic capital are more likely to use confrontational strategies to resolve administrative disputes.

Hypothesis 4.2: Private enterprises with more political capital are more likely to use confrontational strategies to resolve administrative disputes.

\section{Data and methods \\ Data}

We use the Chinese Private Entrepreneur Survey 2006 (hereafter CPES2006), which selects the sample based on the distribution of enterprise scale and industrial structure recorded by the China Statistical Yearbook. The survey is operated by the Federation of Industry and Commerce and Administration of Industry and Commerce at the provincial, municipal, and district levels. The interviewees are limited to the corporate representatives of private enterprises. Thus, CPES2006 covers private enterprises in different industries and different scales from 31 provinces, municipalities, and autonomous regions of China. It is one of the most authoritative datasets in the field of Chinese private enterprises. CPES2006 retrieved 3837 valid questionnaires, among which 1785 provide a valid response to strategy selection in resolving disputes. After listwise deletion, the final sample size is 1563.

\section{Variables}

\section{Dependent variables}

Based on existing operationalization procedure (Chen 2009; Chen and Wu 2010; Fan et al. 2016; Wagner-Pacifici and Hall 2012), we divided the strategies for coping with disputes into four types: the confrontation type, the association type, the formal government agency type, and the informal type.

CPES2006 asks the interviewee to identify their usual strategy in resolving administrative disputes with government agencies from the following ${ }^{6}$ : (a) enduring in silence, (b) private negotiation in informal ways, (c) asking for help from the local government or superior government agencies, (d) initiating arbitration or suing the government agency, (e) resorting to the Federation of Industry and Commerce or the Private Enterprises' Association, (f) uniting autonomously to exert pressure, (g) resorting to the newspapers and other public media, and (h) other ways. We categorized the original options into the four types.

We argue that whether to respond to the dispute and what specific strategy to use to resolve disputes are essentially two different decision processes. Faced with administrative disputes, the choice between silently suffering or fighting back is influenced not only by the potential loss and the characteristics of the dispute but also by the personality of the individual entrepreneur, which is difficult to measure or control directly. However, once the enterprise decides to resolve the dispute through concrete strategies, it means the dispute has developed to a certain stage that the enterprise has to respond. The major difference stems from what specific strategy the enterprise selects after evaluating its extractable resources and bargaining power. Thus, we divided the analysis into two parts. First, we analyze what factors influence 
the decision of resolving a dispute instead of putting up with it. Second, we analyze what factors influence the selection among the four types of resolution strategies. ${ }^{7}$

\section{Independent variable}

The key independent variable of this research is economic capital, referring to the private enterprise's bargaining power with the local government derived from its economic contribution to local economic development. This can be measured by entrepreneurial income, annual sales, and annual investments. We used the total amount of tax payment in 2005 for two reasons. First, from the perspective of fiscal sociology, tax is definitely the key mechanism that configures the state-business relationship (Zhang 2017). Second, compared to annual sales and investments, tax amount directly measures the specific contribution of one enterprise to the local fiscal revenue, and thus reflects the bargaining power more precisely. To reduce the fluctuation of variance, we took the natural logarithm of the tax amount in 2005 (Bland et al. 2013).

\section{Control variables}

We also added individual, organizational, and regional factors for control variables. Previous research demonstrates that individual factors influence the possibility that private entrepreneurs acquire a formal political identity (Chen et al. 2008; Lu 2013). Party membership was categorized into members of Chinese Communist Party (hereafter CCP), and other. The level of education was categorized into four types: junior high school and below, high school, technical college, and undergraduate or above. The involvement of associations was measured by membership in the registered business associations supervised by the government.

On the organizational level, we took political connections, age of enterprise, and the number of employees. The political connections of a private enterprise reflect the extent to which it is co-opted into the party-state (Dickson 2003). It influences the private entrepreneur's extractable resources, political recognition, and knowledge about the government, which then influence his/her strategy selection. We measured political connections by whether they served as members of the People's Congress (hereafter PC) or the Chinese People's Political Consultative conference (CPPCC). We basically hypothesize that the political connection of the private entrepreneur is equal to the political resources possessed by the enterprise itself. Age of a private enterprise is measured by its time of establishment, which is classified into three periods: 1978-1992, 1993-2002, and 2003-2006. The number of employees measures the enterprise's scale, and also reflects the enterprise's contribution to the local economy.

On the regional level, we controlled the enterprise's place of registration, regional economic development, and development of regional private economy. Existing research points out that the local government may play different roles in different areas with specific characteristics of the state-business relationship (Keng 2010; Zhang 2014). We identified the east, the middle, and the west of China. Regional economic development was measured by the provincial GDP in 2005. The level of regional private economy was measured by the regional private economy index (Fan et al. 2011) (Table 1). 
Table 1 Four types of strategies

\begin{tabular}{ll}
\hline Type & Original option \\
\hline Confrontation & Initiating arbitration or suing the government agency \\
& Uniting autonomously to exert pressure \\
& Resorting to the newspapers and other public media \\
& Resorting to the Federation of Industry and Commerce or the Private \\
Enterprises' Association
\end{tabular}

Model

Since the first dependent variable- "whether or not action was taken to resolve a dispute"-is dichotomous, we used the binary logit regression to analyze it. We used the multi-nominal logit regression (hereafter MNL) to analyze the strategy selection resolving administrative disputes. We then conducted the robust test with the sequential logit model (hereafter SLM) (Buis 2011). In the end, nonlinear probability models (Karlson et al. 2012) were used to decompose the total effect of a variable into direct and indirect parts.

\section{Findings}

\section{Descriptive statistics}

Table 2 displays the descriptive characteristics of variables. Faced with administrative disputes, $18.62 \%$ of the sample chose to endure in silence, $42.26 \%$ would seek help from the local government or the superior government agencies, $14.84 \%$ would negotiate privately in informal ways, $11.17 \%$ would resort to business associations, and $8.51 \%$ would use confrontational strategies.

\section{To take action or not}

Table 3 displays the results of the binary logit regression on whether to take action to resolve disputes. We took only the natural logarithm of the tax number in 2005 in model 1, and added its square in model 2. Model 3 is the full model. The Chi-square values are significant under the degrees of freedom of models 1,2 , and 3 . According to model 1, without controlling other variables, when the natural logarithm of the tax amount in 2005 increases by one unit, the possibility that the enterprise takes action increases by $6.24 \%\left(\mathrm{e}^{0.0605}-1\right)$. According to model 2 , along with the increase of the tax, the possibility that the private enterprise takes action first increases and then decreases. In model 3 , the effect of tax is robust even with control variables added. The possibility that CCP members take action is significantly lower than for non-CCP members. Private entrepreneurs with a higher level of education (undergraduate and above) are more inclined to endure disputes silently. ${ }^{8}$ The organizational and regional variables did not pass the significance test.

\section{Strategy selection}

Table 4 reports the preliminary results of the MNL regression on the strategy selection. Models 4.1, 4.2, and 4.3 take the strategy of "formal government agency" as 
Table 2 Descriptive statistics $(N=1563)$

\begin{tabular}{|c|c|}
\hline Variables & Percentage/mean \\
\hline \multicolumn{2}{|l|}{ Gender } \\
\hline Male & 87.01 \\
\hline Female & 12.99 \\
\hline \multicolumn{2}{|l|}{ CCP membership } \\
\hline Yes & 62.32 \\
\hline No & 37.68 \\
\hline \multicolumn{2}{|l|}{ Period of establishment } \\
\hline 1978-1992 & 10.75 \\
\hline 1993-2002 & 65.52 \\
\hline $2003-2006$ & 23.74 \\
\hline \multicolumn{2}{|l|}{ Education } \\
\hline Junior high school and below & 14.40 \\
\hline High school & 34.68 \\
\hline Technical college & 32.12 \\
\hline Undergraduate or above & 18.81 \\
\hline Age & $44.32(7.95)$ \\
\hline Tax amount (In) & $3.60(1.89)$ \\
\hline Number of employees (In) & $3.23(1.35)$ \\
\hline \multicolumn{2}{|l|}{ Associational involvement } \\
\hline Yes & 67.37 \\
\hline No & 32.63 \\
\hline \multicolumn{2}{|l|}{ Political connection } \\
\hline Yes & 40.63 \\
\hline No & 59.37 \\
\hline \multicolumn{2}{|l|}{ Region } \\
\hline East & 63.79 \\
\hline Middle & 22.97 \\
\hline West & 13.24 \\
\hline \multicolumn{2}{|l|}{ Resolution strategy } \\
\hline Formal government agencies & 46.26 \\
\hline Association & 11.77 \\
\hline Enduring in silence & 18.62 \\
\hline Confrontation & 8.51 \\
\hline Informal & 14.84 \\
\hline Development of Private economy & $7.73(2.19)$ \\
\hline GDP/100 (hundred million) & $11.11(6.34)$ \\
\hline
\end{tabular}

Standard errors in parentheses

the reference category. Models 4.4 and 4.5 take the strategy of "association" as the reference category. Model 4.6 simply compares the strategies of "informal" and "confrontation."

On the individual level, gender, age, and education exert no significant effects on strategy selection. As for the period of establishment, compared to enterprises established in 1978-1992, private enterprises established in 1993-2002 are significantly less likely to resort to business associations rather than government agencies. 
Table 3 Parameter estimates for taking action $(N=1563)$

\begin{tabular}{|c|c|c|c|}
\hline & Model 1 & Model 2 & Model 3 \\
\hline & Coefficient S. Er. & Coefficient S. Er. & Coefficient S. Er. \\
\hline $\operatorname{Tax}(\operatorname{In})$ & $0.061^{+}(0.034)$ & $-0.113(0.107)$ & $-0.143(0.109)$ \\
\hline Square of Tax(In) & & $0.027^{+}(0.016)$ & $0.026^{+}(0.016)$ \\
\hline Female & & & $-0.164(0.188)$ \\
\hline Age & & & $-0.001(0.009)$ \\
\hline CCP & & & $-0.263^{+}(0.148)$ \\
\hline \multicolumn{4}{|l|}{ Edu. } \\
\hline High school & & & $-0.014(0.218)$ \\
\hline Technical college & & & $-0.222(0.222)$ \\
\hline Undergraduate and above & & & $-0.427^{+}(0.240)$ \\
\hline Political connection & & & $0.236(0.152)$ \\
\hline Association & & & $-0.063(0.149)$ \\
\hline \multicolumn{4}{|l|}{ Establishment } \\
\hline 1993-2002 & & & $0.379^{+}(0.214)$ \\
\hline $2003-2006$ & & & $0.309(0.244)$ \\
\hline Employment (In) & & & $0.0921(0.059)$ \\
\hline \multicolumn{4}{|l|}{ Region } \\
\hline Middle & & & $0.359(0.241)$ \\
\hline West & & & $-0.144(0.295)$ \\
\hline Private economy level & & & $0.055(0.065)$ \\
\hline GDP/100 & & & $0.028(0.019)$ \\
\hline Constant & $1.261^{* * *}(0.135)$ & $1.449^{* * *}(0.179)$ & $0.569(0.554)$ \\
\hline Log likelihood & -749.68 & -748.08 & -722.16 \\
\hline
\end{tabular}

Robust standard error in parentheses

${ }^{* * *} p<.001 ;{ }^{* *} p<.01 ;{ }^{*} p<0.05 ;+p<0.1$

However, there is no significant difference between the group established in 19781992 and that in 2003-2006. Compared to the group established in 1978-1992, the group in 1993-2002 significantly prefers informal ways than associations. Private enterprises joining business associations significantly prefer associations rather than informal ways to resolve disputes. The number of employees is significantly positively associated with the preference for government agencies.

Table 4 also demonstrates that economic capital and organizational political connections do not have significant effects on the selection of confrontational strategies. However, individual political capital denoted by CCP membership does exert significant effects. The possibility that CCP members select confrontation rather than government agencies is higher than that of non-CCP members by $70.06 \%\left(\mathrm{e}^{0.531}-1\right)$. The possibility that CCP members select confrontation rather than informal ways is also significantly higher. To summarize, the above findings do not support hypothesis 4.1, but do support hypothesis 4.2 to a great extent. Individual political identity instead of enterprise scale influences private entrepreneurs' selection of confrontational strategies.

On the regional level, compared to private enterprises in eastern areas, those in the middle and western areas of China are more likely to select formal government agencies and informal ways to resolve disputes. Compared to private enterprises in eastern areas, those in middle areas prefer associations to informal ways. However, 
Table 4 MNL models predicting strategy selection $(N=1272)$

\begin{tabular}{|c|c|c|c|c|c|c|}
\hline & Model 4.1 & Model 4.2 & Model 4.3 & Model 4.4 & Model 4.5 & Model 4.6 \\
\hline & $\begin{array}{l}\text { Association } \\
\text { vs } \\
\text { Government }\end{array}$ & $\begin{array}{l}\text { Confrontation vs } \\
\text { Government }\end{array}$ & $\begin{array}{l}\text { Informal vs } \\
\text { Government }\end{array}$ & $\begin{array}{l}\text { Confrontation vs } \\
\text { Association }\end{array}$ & $\begin{array}{l}\text { Informal vs } \\
\text { Association }\end{array}$ & $\begin{array}{l}\text { Informal vs } \\
\text { Confrontation }\end{array}$ \\
\hline $\operatorname{Tax}(\ln )$ & $\begin{array}{l}-0.133^{* *} \\
(0.049)\end{array}$ & $-0.084(0.058)$ & $-0.089^{+}(0.048)$ & $0.049(0.067)$ & $0.044(0.059)$ & $-0.005(0.066)$ \\
\hline CCP & $0.141(0.185)$ & $0.531^{*}(0.216)$ & $0.125(0.168)$ & $0.390(0.261)$ & $-0.016(0.221)$ & $-0.405^{+}(0.246)$ \\
\hline $\begin{array}{l}\text { Political } \\
\text { connections }\end{array}$ & $0.102(0.189)$ & $-0.102(0.213)$ & $-0.169(0.184)$ & $-0.204(0.256)$ & $-0.271(0.234)$ & $-0.068(0.254)$ \\
\hline Association & $0.325(0.200)$ & $-0.178(0.215)$ & $-0.354^{*}(0.168)$ & $-0.503^{+}(0.266)$ & $-0.679 * *(0.228)$ & $-0.176(0.242)$ \\
\hline \multicolumn{7}{|l|}{ Establishment } \\
\hline \multirow[t]{2}{*}{ 1993-2002 } & $-0.528^{*}$ & -0.440 & 0.026 & 0.088 & 0.554 & 0.466 \\
\hline & $(0.260)$ & $(0.307)$ & $(0.286)$ & $(0.349)$ & $(0.337)$ & $(0.369)$ \\
\hline \multirow[t]{2}{*}{ 2003-2006 } & -0.471 & -0.301 & -0.024 & 0.169 & 0.447 & 0.277 \\
\hline & $(0.306)$ & $(0.342)$ & $(0.329)$ & $(0.395)$ & $(0.388)$ & $(0.414)$ \\
\hline \multirow{2}{*}{$\begin{array}{l}\text { Employment } \\
\text { (In) }\end{array}$} & $-0.149^{+}$ & -0.001 & $-0.135^{*}$ & 0.149 & 0.014 & -0.135 \\
\hline & $(0.077)$ & $(0.084)$ & $(0.068)$ & $(0.103)$ & $(0.091)$ & $(0.096)$ \\
\hline \multicolumn{7}{|l|}{ Region } \\
\hline \multirow[t]{2}{*}{ Middle } & -0.295 & $-0.994^{* *}$ & $-1.130^{* * *}$ & -0.698 & $-0.835^{*}$ & -0.137 \\
\hline & $(0.306)$ & $(0.383)$ & $(0.316)$ & $(0.438)$ & $(0.375)$ & $(0.438)$ \\
\hline \multirow[t]{2}{*}{ West } & $-0.876^{+}$ & $-0.964^{+}$ & -0.219 & -0.088 & 0.657 & 0.745 \\
\hline & $(0.450)$ & $(0.519)$ & $(0.363)$ & $(0.628)$ & $(0.505)$ & $(0.570)$ \\
\hline \multirow{2}{*}{$\begin{array}{l}\text { Private } \\
\text { economy level }\end{array}$} & -0.054 & -0.126 & -0.077 & -0.072 & -0.023 & 0.049 \\
\hline & $(0.087)$ & $(0.096)$ & $(0.086)$ & $(0.109)$ & $(0.101)$ & $(0.108)$ \\
\hline \multirow{2}{*}{$\begin{array}{l}\text { GDP/100 } \\
\text { (hundred } \\
\text { million) }\end{array}$} & -0.034 & -0.033 & $-0.042^{+}$ & 0.001 & -0.008 & -0.009 \\
\hline & $(0.026)$ & $(0.026)$ & $(0.024)$ & $(0.032)$ & $(0.032)$ & $(0.032)$ \\
\hline Other CVs & YES & YES & YES & YES & YES & YES \\
\hline \multirow[t]{2}{*}{ Constant } & 0.670 & 0.452 & 1.036 & -0.219 & 0.366 & 0.584 \\
\hline & $(0.730)$ & $(0.814)$ & $(0.696)$ & $(0.935)$ & $(0.830)$ & $(0.900)$ \\
\hline Log likelihood & -1394.15 & & & & & \\
\hline
\end{tabular}

Robust standard error in parentheses

Other CVs include gender, age, and education

${ }^{* * *} p<.001 ;{ }^{* *} p<.01 ;{ }^{*} p<0.05 ;+p<0.1$

the lack of significant difference between the western group and the eastern group might be a potential topic for further discussion. Private enterprises that have membership in business associations select associations more frequently than confrontation or informal ways. This simply reflects that fact that association members have a higher consciousness of and ability in using the associational approach. The regional private economy level and the provincial GDP do not exert significant effects.

Models 4.1, 4.2, and 4.3 also demonstrate that the tax figures are positively associated with the preference for formal government agencies over associations, confrontation, or informal ways. For example, when the natural logarithm of tax amount increases by one unit, the possibility of choosing associations over government agencies decreases by $12.45 \%\left(1-1 / \mathrm{e}^{0.133}\right)$. Hypothesis 1 is supported.

Table 5 continues to test hypothesis 2 and hypothesis 3 . We added the square of the natural logarithm of the tax figure in model 5.1 and model 5.2. In model 5.1, the square term of tax has a negative coefficient, which indicates an inverted- $U$ shape for the 
Table 5 Further MNL models predicting strategy selection $(N=1272)$

\begin{tabular}{lllll}
\hline & Tax $(\operatorname{In})$ & Square of $\operatorname{tax}(\operatorname{In})$ & Cube of tax $(\operatorname{In})$ & Other CVs \\
\hline Model 5.1 & 0.081 & -0.032 & - & Yes \\
& $(0.143)$ & $(0.020)$ & - & - \\
Model 5.2 & $0.266^{+}$ & $-0.055^{* *}$ & - & Yes \\
& $(0.141)$ & $(0.020)$ & - & - \\
Model 6.1 & $-0.317^{+}$ & $0.139^{*}$ & $-0.018^{* *}$ & Yes \\
& $(0.175)$ & $(0.061)$ & $(0.007)$ & - \\
\hline
\end{tabular}

Robust standard error in parentheses

Other CVs include gender, age, education level, CCP membership, association involvement, employment figure, period of establishment, private economy level, region, and provincial GDP

${ }^{* * *} p<.001 ;{ }^{* *} p<.01 ;{ }^{*} p<0.05 ;+p<0.1$

relationship between economic capital and selection of the association strategy. However, it is not statistically significant. To further test hypothesis 3 , we added the cube of tax into model 5.1. The resulting model 6.1 shows significance for both the cube term and the square term. For those private enterprises that have the lowest economic capital, the possibility that they choose associations over government agencies for dispute resolution decreases quickly with the increase of economic capital. When an enterprise's economic capital is in the middle or high range, the possibility of selecting associations over government agencies first decreases slowly, but is followed by a sharp increase. This indicates that for different economic scales, the pattern of economic capital's effects on strategy selection is different. In model 5.2, all the terms of economic capital are significant. This clearly demonstrates that along with the increase of economic capital, the possibility of selecting informal ways over government agencies first increases and then decreases-also
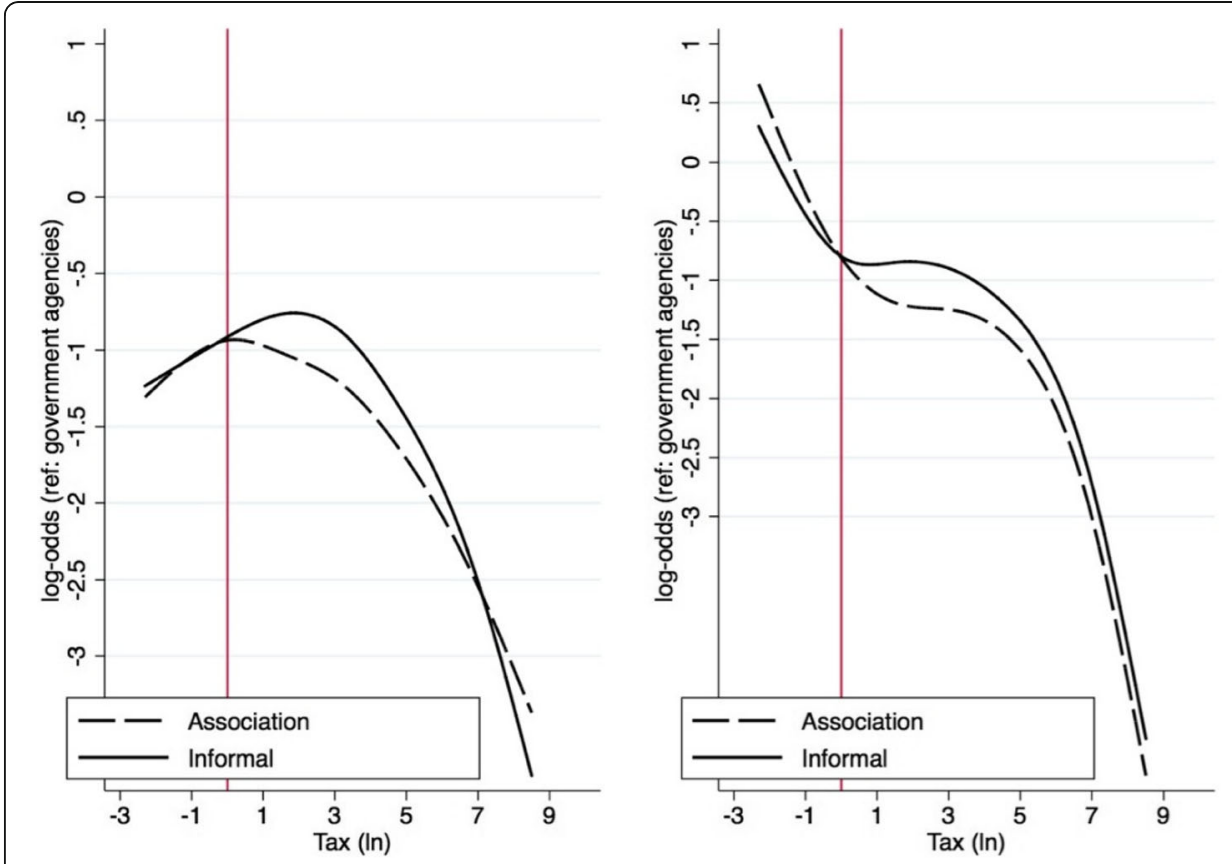

Fig. 2 Size of private enterprises and strategy selection. The solid line stands for the log-odds of choosing informal strategies against the directly communicating with government agencies. The dashed line stands for the log-odds of choosing associational channels against the directly communicating with government agencies 
an inverted-U shape pattern. To summarize, both hypothesis 2 and hypothesis 3 are supported, as displayed in Fig. 2.

\section{Robustness test}

This article uses the SLM to test robustness. As Table 6 shows, model 7 compares "enduring in silence" with the four resolution strategies as a whole. It demonstrates that CCP members are significantly less likely to take action than non-CCP members. Model 8 compares "formal government agencies" with the other three resolution strategies as a whole. It demonstrates that along with the increase of tax amount, the possibility of selecting government agencies first increases and then decreases $(p<$ 0.01). Model 9 compares "association" with the combination of "confrontation" and "informal ways." It demonstrates no significant differences. Model 10 compares "confrontation" with "informal ways" and also demonstrates no significant differences. The results of SLM support the robustness of Tables 4 and 5 .

\section{Conclusions}

Departing from the empirics, this article reveals the variation in the state-business relationship in contemporary China as a result of the economic capital possessed by private enterprises. In addition to the regime's characteristics, features of the business itself also shape its relationship with the authority. Private enterprises with different levels of economic capital enjoy different levels of bargaining power and thus construct essentially different relationships with the local government. Private enterprises with high economic capital are preferred and supported by the local state because of

Table 6 Seqlogit models predicting strategy selection $(N=1563)$

\begin{tabular}{lllll}
\hline & Model 7 & Model 8 & Model 9 & Model 10 \\
\hline Tax (In) & C2 C3 C4 C5 vs C1 & C3 C4 C5 vs C2 & C4 C5 vs C3 & C5 vs C4 \\
Square of tax (In) & $-0.143(0.109)$ & $0.136(0.099)$ & $0.051(0.157)$ & $0.311(0.195)$ \\
CCP & $0.025(0.016)$ & $-0.036^{* *}(0.014)$ & $-0.001(0.024)$ & $-0.047(0.029)$ \\
Political connection & $-0.263^{+}(0.148)$ & $0.209^{+}(0.126)$ & $0.022(0.206)$ & $-0.493^{+}(0.266)$ \\
Association & $0.236(0.152)$ & $-0.060(0.132)$ & $-0.256(0.214)$ & $-0.015(0.264)$ \\
Establishment & $-0.063(0.149)$ & $-0.085(0.131)$ & $-0.620^{* *}(0.213)$ & $-0.169(0.247)$ \\
1993-2002 & & & & \\
2003-2006 & $0.379^{+}(0.214)$ & $-0.317(0.200)$ & $0.441(0.307)$ & $0.546(0.393)$ \\
Employment(In) & $0.309(0.244)$ & $-0.258(0.230)$ & $0.319(0.354)$ & $0.472(0.444)$ \\
Region & $0.092(0.059)$ & $-0.101^{+}(0.052)$ & $0.033(0.088)$ & $-0.173(0.107)$ \\
Middle & & & & $-0.266(0.411)$ \\
West & $0.359(0.241)$ & $-0.775^{* * *}(0.225)$ & $-0.807^{*}(0.337)$ & $0.700(0.527)$ \\
Private economy & $-0.144(0.295)$ & $-0.575^{*}(0.291)$ & $0.406(0.478)$ & $0.024(0.122)$ \\
GDP/100 (hundred million) & $0.028(0.019)$ & $-0.038^{*}(0.017)$ & $0.003(0.028)$ & $-0.001(0.033)$ \\
Other CVs & Yes & Yes & Yes & Yes \\
Constant & $0.569(0.554)$ & $1.674^{* *}(0.540)$ & $1.041(0.852)$ & $0.447(0.993)$ \\
\hline
\end{tabular}

Robust standard error in parentheses

Other CVs include sexuality, gender, age, and education level

${ }^{* * *} p<.001 ;{ }^{* *} p<.01 ;{ }^{*} p<0.05 ;+p<0.1$ 
their prominent contribution to the local economy. They are more likely to obtain institutional opportunities of direct and individual communication with the government. Thus, they also avoid using business associations to solve practical problems. Private enterprises with medium economic capital usually lack these large enterprises' institutional priority. They are also afraid of the political risks and economic loss entailed by confrontation. Medium-sized private enterprises are therefore more inclined to build business associations or informal clientelist networks to resolve administrative disputes. CCP membership instead of economic capital significantly influences the selection of confrontation over informal ways. This implies that ideology and consciousness rather than bargaining power are crucial when using confrontational strategies.

These findings have four implications. First, they suggest it may be time to reflect on the domination of the clientelism perspective and pay more attention to the heterogeneity of the state-business relationship in contemporary China. Private entrepreneurs' reliance on clientelist networks, employment of formal institutions, and actual involvement in business associations vary according to their economic capital.

Second, the findings verify the political advantages and bargaining power enjoyed by a few large private enterprises. There is still a significant gap between the contingent bargaining power in the specific context and structural political power. Yet the phenomenon that either private entrepreneurs employ institutional channels to pursue their goals, or small and petty entrepreneurs perform collective resistance to pressure local government agencies is redefining the boundary of state power and the way that the state influences social groups. In this sense, social groups have stepped into the real political process and play a substantial role. Taking a further step, we conclude that Chinese businessmen have actually transformed their economic status into political power, albeit in a limited sense. Again, the specific extent and context of this transformation needs further discussion.

Third, small- and medium-sized private enterprises lack political advantages and are more likely to rely on business associations and informal networks. This denotes that a kind of associational activism is emerging among some private entrepreneurs in contemporary China. However, the active involvement of associations and informal networks do not contradict each other. In China, business associations are institutional arrangements that usually also serve as important platforms to nurture social networks among officials and private entrepreneurs (Wank 1999). Thus, business associations in contemporary China have the dual function of serving as institutional conduits and producing clientelist networks.

Last but not least, the diversity in the state-business relationship leads us to question to what extent can Chinese private entrepreneurs be regarded as a class with solidarity and a unified identity. The collective contentious action by small and petty entrepreneurs challenges the regime's authority, large private entrepreneurs are co-opted by the state and exchange loyalty for advantages, clearly contributing to the regime's resilience. In some sense, marketization in China may not lead to the emergence of a unified capitalist class, but continue to deepen the internal segmentation within the entrepreneur group. The transformation of economic power to political power is configured both by the institutional context of the polity and the characteristics of the private economic sector. 


\section{Endnotes}

${ }^{1}$ For example, "American Media: The Super Rich Who Shape Chinese Politics, Private Enterprises Influence Government Policies” (美媒“塑造中国”的超级富豪,民营企业开 始影响政策制定), http://oversea.huanqiu.com/article/2016-03/8654420.html, accessed on Sept. 18, 2018.

${ }^{2}$ For example, "Fireworks Enterprises Sue the Provincial Government and Win in Anhui" (安徽花炮企业状告省政府胜诉), http://news.youth.cn/gn/201504/t20150424_6596483.htm, accessed on Sept. 18, 2018; “Ten Classical Cases that the Supreme People's Court Protects Private Economy” (最高法保护民营经济十大经典案例) http://www.zytzb.gov.cn/tzb2010/ S1818/201604/40e05cc90a7049dba6c4051967c2069f.shtml, accessed on Sept. 18, 2018.

${ }^{3}$ We acknowledge that many qualitative research works have studied conflict solution strategies, but this paper focuses on the relevant quantitative studies.

${ }^{4}$ Interview, Guangdong, March 2016.

${ }^{5}$ For example, "Shisanhang Protest Collectively: The urgent transition to electronic economy?" (十三行抗议事件始末:电商转型刻不容缓?),http://www.sohu.com/a/35511618_127320, accessed on Sept. 18, 2018.

${ }^{6}$ The options include B36e1, B36f1, B36g1, and B36h1. Except for B36e1, the percentage of the missing values of the rest all exceed $90 \%$. We thus focus on B36e1, while suspecting the reliability of B36f1, B36g1, and B36h1.

${ }^{7}$ In the first drafts, we were not cautious enough about the endogeneity problem. We would like to thank the anonymous reviewers for reminding us of this.

${ }^{8}$ This pattern contradicts existing findings on civil disputes. Chen and Wu (2010) find that social groups with a higher level of education were less tolerant of disputes. This difference may indicate that the action logic of private entrepreneurs may differ from that of other social groups. This subject needs further inquiry.

\section{Abbreviations}

CCP: Chinese Communist Party; CGSS2005: Chinese General Social Survey 2005; CPC: Chinese Peoples' Congress; CPES: Chinese Private Entrepreneur Survey; CPPCC: Chinese People's Political Consultative Conference; GDP: Gross domestic production; MNL: Multi-nominal logit regression; SLM: Sequential logit model

\section{Acknowledgements}

This paper was presented at the forum "Institution, Behavior and Idea: New Economic Context and Sociological Studies" at the Chinese Annual Sociological Conference 2016. We would like to thank Yong Gui, Xiaochun Huang, Dongya Huang, Shiding Liu, Peng Lu, Changdong Zhang, Xiang Zhang, Dong Zhang, Hua Zhang, Diyang Zeng, and anonymous reviewers for their suggestions.

The data used in this paper is drawn from the China Private Entrepreneur Survey 2006, which is publicly available. The Research Center for Private Enterprises at Chinese Academy of Social Sciences (PCPE-CASS) is the authorized organization that manages and issues the survey data. We appreciate the data support from the above organization.

Funding

This research is supported by the National (China) Social Science Foundation (Grant no.17CSH074, The Publicity of Social Organization and its Influence on Grassroots Governance in Urban China).

\section{Authors' contributions}

YJ contributed to the study's conception and theoretical discussion. FX contributed to the theoretical discussion, quantitative analyses, and research design. YJ wrote the manuscript except for the interpretation of statistical findings. Both authors read and approved the final manuscript.

Competing interests

The authors declare that they have no competing interests.
}

\section{Publisher's Note}

Springer Nature remains neutral with regard to jurisdictional claims in published maps and institutional affiliations. 
Author details

${ }^{1}$ Shanghai University, Shangda Road 99, Shanghai, China. ${ }^{2}$ Zhejiang University, Yuhangtang Road 866, Hangzhou, Zhejiang, China.

Received: 30 October 2018 Accepted: 2 December 2018

Published online: 10 January 2019

\section{References}

Ang, Yuen Yuen, and Nan Jia. 2014. Perverse complementarity: political connections and the use of courts among private firms in China. The Journal of Politics 72 (2): 318-332.

Bland, J.M., D.G. Altman, and F.J. Rohlf. 2013. In defence of logarithmic transformations. Statistics in Medicine 32 (21): $3766-3768$.

Buis, Maarten L. 2011. The consequences of unobserved heterogeneity in a sequential logit model. Research in Social Stratification and Mobility 29 (3): 247-262.

Cai, Yongshun. 2008. Social conflicts and modes of action in China. The China Journal 59: 89-109.

Chen, Jinhua. 2009. Institutional options for administrative disputes in China-from the perspective of the needs of the public. Social Science in China 6: 144-160.

Chen, Jinhua, and Xiaogang Wu. 2010. Social class and civic disputes resolutions: social differentiation and legal development in transitional China. Sociological Studies 2: 151-179.

Chen, Zhao, Ming Lu, and Junzhi He. 2008. Power and political participation of entrepreneurs. The Journal of World Economy 6: 39-49.

Deng, Guosheng, and Scott Kennedy. 2010. Big business and industry association lobbying in China: the paradox of contrasting styles. The China Journal 63: 89-109.

Dickson, Bruce. 2009. Who consents to the'Beijing consensus'? Crony communism in China. (http://ww2.usc.cuhk.edu.hk/ PaperCollection/webmanager/wkfiles/7151_1_paper.pdf)

Dickson, Bruce J. 2003. Red capitalists in China: the party, private entrepreneurs and prospects for political change. Cambridge: Cambridge University Press.

Domhoff, W. 2009. In Who Rules America: power, politics and social change, trans, ed. Peng Lu and Xiang Wen. Nanjing: Yilin Press.

Dong, Haijun. 2008. The weak identity as a weapon: subaltern politics of the peasant resistance for rights. Society 4: 34-58.

Fan, Gang, Xiaolu Wang, and Hengpeng Zhu. 2011. The Marketization Index-2011 Annual Report of Regional Marketization. Beijing: Economic Science Press.

Fan, Xiaoguang, Ming Lei, and Xiao Yang. 2016. The lineage networks and civil disputes resolution in rural China. Xuehai 6: 60-68.

Gao, Yongqiang, and Zhilong Tian. 2006. How firms influence the government policy decision-making in China. Singapore Management Review 28 (1): 73-85.

Guthrie, Gouglas. 1998. The declining significance of Guanxi in China's economic transition. The China Quarterly 154: 254-282.

Haggard, S., S. Maxfield, and B.R. Schneider. 1997. Theories of business and business-state relations. In Business and the state in developing countries, ed. S. Maxfield and Ben Ross Schneider, 36-63. Ithaca, NY: Cornell University Press.

Huang, Dongya. 2013. How do entrepreneurs influence the local policy process? A case study of typology construction from the state-centered perspective. Sociological Studies 5: 172-196.

Huang, Dongya. 2014a. Private entrepreneurs and political development in China: theoretical imagination of private entrepreneurs in the marketization as a class and its reflection. Society 4: 138-164.

Huang, Dongya, and Chuanmin Chen. 2015. Revolving out of the party-state: the Xiahai entrepreneurs and circumscribing government power in China. The Journal of Contemporary China 25 (97): 41-58.

Ji, Yingying. 2015. The inner differentiation of business associations: how social foundation influences the organizational cohesion. Journal of Public Management 1: 107-116.

Ji, Yingying. 2016. Diversified relationship between the transforming state and business associations: an organizational analysis. Sociological Studies 2: 149-169.

Jia, Xijin, Hengchao Shen, and Wenan Hu. 2004. Business associations in transitions: role, function and administrative system. Beijing: Social science Academic Press.

Jiang, Hua, Jianmin Zhang, and Ying Zhou. 2011. Interests alignment: an analytical framework of the state and society relations in transitional China. Sociological Studies 3: 136-152.

Karlson, Kristian Bernt, Anders Holm, and Richard Breen. 2012. Comparing regression coefficients between same-sample nested models using logit and Probit: a new method. Sociological Methodology 42 (1): 286-313.

Keng, S. 2010. Developing into a developmental state: explaining the changing government-business relationships behind the Kunshan Miracle. In Dynamics of Local Governance in China during the Reform Era, ed. T.K. Leng and Y.H. Chu, 225-271. Plymouth: Lexington Books.

Keng, Shu, and Luhui Chen. 2001. Prosperous with the market: the innovative transition of the local network in a town of Huabei. Issue and Study 40 (3): 83-108.

Keng, Shu, and Wei Chen. 2015. Government-corporate relations, two-way rent seeking and the FDI miracle in China. Sociological Studies 5: 141-163.

Kennedy, Scott. 2005. The business of lobbying in China. Boston, MA: Harvard University Press.

Lee, Ching Kwan, and Yonghong Zhang. 2013. The power of instability: unraveling the microfoundations of bargained authoritarianism in China. American Journal of Sociology 118 (6): 1475-1508.

Li, J. 2013. Dare you sue the tax collector? An empirical study of administrative lawsuits against tax agencies in China. Pacific Rim Law and Policy Journal 23 (1): 57-112.

Lu, Peng. 2013. An empirical analysis on the impact factors of being representatives in the People's congress and People's political consultative conference for private entrepreneurs. Sociological Studies 4: 154-178.

Lu, Peng. 2016. "From clientelism to protest: a case study of Shanbei oil event." working paper, presented at, 2016. Lanzhou: Chinese Sociological Annual Conference.

Lu, Yilong, and Min Yang. 2010. Relation networks and its influence on rural disputes: a legal sociological study based on CGSS. Xuehai 3: 174-180.

Lucas, John. 1997. The politics of business associations in the developing world. The Journal of Developing Areas 32 (1): 71-96. 
Michelson, Ethan. 2007. Climbing the dispute pagoda: grievances and appeals to the official justice system in rural China. American Sociological Review 72: 459-485.

Salamon, M. Lester, and John Siegfried. 1977. Economic power and political influence: the impact of industry structure on public policy. The American Political Science Review 70 (3): 1026-1043.

Tsai, K.S. 2007. Capitalism without democracy: the private sector in contemporary China. Ithaca, NY: Cornell University Press. Wagner-Pacifici, Robin, and Meredith Hall. 2012. Resolution of social conflict. Annual Review of Sociology 38: 181-199.

Wank, David. 1999. Commodifying communism: business, trust, and politics in a Chinese city. New York: Cambridge University Press.

You, Jong-Sung. 2014. Land reform, inequality, and corruption: a comparative historical study of Korea, Taiwan, and the Philippines. The Korean Journal of International Studies 12 (1): 191-224.

Zhang, Changdong. 2017. A fiscal sociology of authoritarian resilience: developing theory through a case study on China. Sociological Theory 35 (1): 39-63.

Zhang, Han. 2014. Local development state or local entrepreneurial state? A review of local state-Enterprise relationship and local state behaviors. Journal of Public Administration 3: 157-175.

Submit your manuscript to a SpringerOpen ${ }^{\odot}$ journal and benefit from:

- Convenient online submission

- Rigorous peer review

- Open access: articles freely available online

High visibility within the field

- Retaining the copyright to your article

Submit your next manuscript at $\boldsymbol{\nabla}$ springeropen.com 